\title{
Speciated mercury at marine, coastal, and inland sites in New England - Part 1: Temporal variability
}

\author{
H. Mao ${ }^{1}$ and R. Talbot ${ }^{2}$ \\ ${ }^{1}$ Department of Chemistry, State University of New York, College of Environmental Science and Forestry, Syracuse, NY \\ 13210, USA \\ ${ }^{2}$ Department of Earth and Atmospheric Sciences, University of Houston, Houston, TX 77204, USA
}

Correspondence to: H. Mao (hmao@esf.edu)

Received: 27 September 2011 - Published in Atmos. Chem. Phys. Discuss.: 8 December 2011

Revised: 22 May 2012 - Accepted: 23 May 2012 - Published: 8 June 2012

\begin{abstract}
A comprehensive analysis was conducted using long-term continuous measurements of gaseous elemental mercury $\left(\mathrm{Hg}^{0}\right)$, reactive gaseous mercury (RGM), and particulate phase mercury $\left(\mathrm{Hg}^{P}\right)$ at coastal (Thompson Farm, denoted as TF), marine (Appledore Island, denoted as AI), and elevated inland (Pac Monadnock, denoted as PM) sites from the AIRMAP Observatories in southern New Hampshire, USA. Decreasing trends in background $\mathrm{Hg}^{0}$ were identified in the 7.5- and 5.5-yr records at TF and PM with decline rates of 3.3 parts per quadrillion by volume (ppqv) $\mathrm{yr}^{-1}$ and $6.3 \mathrm{ppqv} \mathrm{yr}^{-1}$, respectively. Common characteristics at these sites were the reproducible annual cycle of $\mathrm{Hg}^{0}$ with its maximum in winter-spring and minimum in fall, comprised of a positive trend in the warm season (spring - early fall) and a negative one in the cool season (late fall - winter). Year-to-year variability was observed in the warm season decline in $\mathrm{Hg}^{0}$ at $\mathrm{TF}$ varying from a minimum total (complete) seasonal loss of 43 ppqv in 2009 to a maximum of 92 ppqv in 2005, whereas variability remained small at $\mathrm{AI}$ and PM. The coastal site TF differed from the other two sites with its exceptionally low levels (as low as below 50 ppqv) in the nocturnal inversion layer possibly due to dissolution in dew water. Measurements of $\mathrm{Hg}^{0}$ at PM exhibited the smallest diurnal to annual variability among the three environments, where peak levels rarely exceeded $250 \mathrm{ppqv}$ and the minimum was typically 100 ppqv. It should be noted that summertime diurnal patterns at TF and AI were opposite in phase indicating strong sink(s) for $\mathrm{Hg}^{0}$ during the day in the marine boundary layer, which was consistent with the hypothesis of $\mathrm{Hg}^{0}$ oxidation by halogen radicals there. Mixing ratios of RGM in the coastal and marine boundary layers reached
\end{abstract}

annual maxima in spring and minima in fall, whereas at PM levels were generally below the limit of detection (LOD) except in spring. RGM levels at AI were higher than at TF and $\mathrm{PM}$ indicating a stronger source strength in the marine environment. Mixing ratios of $\mathrm{Hg}^{P}$ at $\mathrm{AI}$ and $\mathrm{TF}$ were close in magnitude to RGM levels and were mostly below 1 ppqv. Diurnal variation in $\mathrm{Hg}^{P}$ was barely discernible at $\mathrm{TF}$ and $\mathrm{AI}$ in spring and summer. Higher levels of $\mathrm{Hg}^{P}$ were observed during the day, while values that were smaller, but above the LOD, occurred at night.

\section{Introduction}

Atmospheric mercury exists in three forms, gaseous elemental mercury $\left(\mathrm{Hg}^{0}\right)$, reactive gaseous mercury (RGM), and particulate mercury $\left(\mathrm{Hg}^{P}\right) . \mathrm{Hg}^{0}$ can be oxidized to RGM, part of which is further transformed to $\mathrm{Hg}^{P}$ on aerosol surfaces. RGM and $\mathrm{Hg}^{P}$ eventually enter the biosphere via dry and wet deposition. $\mathrm{Hg}^{0}$ reportedly has a lifetime of 612 months, whereas RGM and $\mathrm{Hg}^{P}$ are highly soluble and thus are quickly removed from the atmosphere (Schroeder and Munthe, 1998). In general $\mathrm{Hg}^{0}$ comprises $>95 \%$ of total gaseous mercury (TGM $\left.=\mathrm{Hg}^{0}+\mathrm{RGM}\right)$. However, studies suggest that fractions of $\mathrm{Hg}^{0}, \mathrm{RGM}$, and $\mathrm{Hg}^{P}$ of total atmospheric mercury vary geographically due to different land surface types, chemical environments, and human influences.

There have been world-wide measurements of ambient levels of $\mathrm{Hg}^{0}$ and TGM. A recent review by Sprovieri et al. (2010, references therein) summarized that the background level of atmospheric TGM in the Northern 
Hemisphere ranges from 1.5 to $1.7 \mathrm{ng} \mathrm{m}^{-3}$ (168-190 ppqv based on $1 \mathrm{ng} \mathrm{m}^{-3}=112 \mathrm{ppqv}$ in a standard atmosphere at a temperature of $273.15 \mathrm{~K}$ and a pressure of $1013 \mathrm{hPa}$ ). For rural and mountainous sites in the northeastern and southeastern U.S., Sigler and Lee (2006) and Valente et al. (2007) suggested typical levels of $\mathrm{Hg}^{0}$ at $\sim 1.6 \mathrm{ng} \mathrm{m}^{-3}$ (179 ppqv). Our previous study found a regional background level of $\sim 160$ ppqv $\left(1.4 \mathrm{ng} \mathrm{m}^{-3}\right.$ ) in wintertime New England (Mao et al., 2008). In the marine environment, $\mathrm{Hg}^{0}$ is reportedly around $1.6 \mathrm{ng} \mathrm{m}^{-3}$ (179 ppqv) over the North Atlantic (Laurier and Mason, 2007), 1.6-4.7 $\mathrm{ng} \mathrm{m}^{-3}$ over the North Pacific (Laurier et al., 2003), and 0.4-11.2 $\mathrm{ng} \mathrm{m}^{-3}$ (45-1254 ppqv) over the Mediterranean Sea (Sprovieri et al., 2003).

In comparison, there is much less coverage of RGM and $\mathrm{Hg}^{P}$ measurements in space and time. The review by Valente et al. (2007, references therein) suggested that mean RGM and $\mathrm{Hg}^{P}$ concentrations over land were 0.029-0.048 (3$5 \mathrm{ppqv}$ ) and $0.029-0.361 \mathrm{ng} \mathrm{m}^{-3}$ (3-40 ppqv) respectively. Mason et al. (2003, references therein) compiled available oceanic measurements of RGM and $\mathrm{Hg}^{P}$ and reported a wide range of average concentrations. In the marine atmosphere RGM varied from $6( \pm 6) \mathrm{pg} \mathrm{m}^{-3}(0.7 \pm 0.7 \mathrm{ppqv})$ north of $30^{\circ} \mathrm{N}$ over the Pacific (Laurier et al., 2003) to a high of $50( \pm 43) \mathrm{pg} \mathrm{m}^{-3}(5.6 \pm 4.8 \mathrm{ppqv})$ at Bermuda downwind of North America (Sheu, 2001). Over the North Atlantic, Laurier and Mason (2007) found a value of $5.9 \mathrm{pg} \mathrm{m}^{-3}$ (0.7 ppqv) for RGM concentrations averaged over a 10 day period in late summer with maximum values reaching $27 \mathrm{pg} \mathrm{m}^{-3}$ (3 ppqv). For $\mathrm{Hg}^{P}$, a level of $8 \mathrm{pg} \mathrm{m}^{-3}$ (0.9 ppqv) was measured at Mace Head, Ireland (Ebinghaus et al., 2002), compared to much higher values of $31( \pm 44) \mathrm{pg} \mathrm{m}^{-3}$ ( $\left.3 \pm 5 \mathrm{ppqv}\right)$ in coastal Maryland, U.S. (Mason and Sheu, 2002). The four two-week measurement campaigns during the MAMCS project in the Mediterranean region over the 1998-2000 period showed that RGM concentrations in the Mediterranean, far from sources and particularly with onshore winds, were comparable to those in industrial northern Europe (Pirrone et al., 2003).

In the northeastern US, we showed an annual mean RGM mixing ratio of $0.41( \pm 0.93)$ ppqv in 2007 with a range of 0-22 ppqv at Thompson Farm (denoted as TF hereinafter), a rural site on the southern New Hampshire coastline, compared to the annual mean of $0.13( \pm 0.25)$ ppqv and a median below the limit of detection (LOD) (0.1 ppqv) at Pac Monadnock (denoted as PM hereinafter), an elevated (700 $\mathrm{m}$ a.s.1.) inland site (Sigler et al., 2009). In the same study we found mean RGM to be $0.76( \pm 0.88)$ ppqv at a marine site Appledore Island (denoted as AI hereinafter) over July-September 2007, significantly higher than those at the two inland sites during the same time period.

Studies on $\mathrm{Hg}^{0}$ for the time period of the mid1990s to early 2000s in the North Pole did not suggest trends (Steffen et al., 2005; Berg et al., 2004). In a recent study on the long-term trend in background $\mathrm{Hg}^{0}$, Ebinghaus et al. (2011) reported a decline rate of
$-0.028 \pm 0.01 \mathrm{ng} \mathrm{m}^{-3} \mathrm{yr}^{-1}\left(-3.1 \pm 1.1 \mathrm{ppqv} \mathrm{yr}^{-1}\right)$ based on monthly mean values of baseline data for the 1996-2009 period at Mace Head, Ireland. Their analysis suggested that the term "baseline" was the same as the commonly used term "background level" in the literature, which is obtained using a subset of data without direct anthropogenic influence. A decline rate of $-0.034 \pm 0.005 \mathrm{ng} \mathrm{m}^{-3} \mathrm{yr}^{-1}$ $\left(-3.8 \pm 0.6 \mathrm{ppqv}^{-1}\right)$ was found from background data at Cape Point in South Africa by Slemr et al. (2011). Cole and Steffen (2010) found a $0.6 \% \mathrm{yr}^{-1}$ decreasing trend in $\mathrm{Hg}^{0}$ at Alert, Canada over the time period of 1995-2007. In this study, we presented the first opportunity to look into possible trends in background $\mathrm{Hg}^{0}$ at midlatitudes in North America.

Multi-year continuous measurements of $\mathrm{Hg}^{0}, \mathrm{RGM}$, and $\mathrm{Hg}^{P}$ have been conducted at inland, coastal, and marine locations from the AIRMAP Observatories. Our previous study (Mao et al., 2008) presented $\mathrm{Hg}^{0}$ datasets spanning $3.5 \mathrm{yr}$ at $\mathrm{TF}, \sim 2 \mathrm{yr}$ at PM, and 2 months at AI. This study covers $\mathrm{Hg}^{0}$ data spanning $7.5 \mathrm{yr}$ at $\mathrm{TF}, 5.5 \mathrm{yr}$ at $\mathrm{PM}$, and $\sim 3 \mathrm{yr}$ at AI. These much longer datasets enabled us to examine the trends in background $\mathrm{Hg}^{0}$ and to investigate interesting characteristics in interannual variability of the annual cycles in different geographical environments. In addition, this study presented new data including $\sim 4$ yr of RGM measurements at TF, $\sim 2 \mathrm{yr}$ at PM, and $2 \mathrm{yr}$ on $\mathrm{AI}$, as well as $1.5 \mathrm{yr}$ of $\mathrm{Hg}^{P}$ data each at TF and AI. Overall, we provide an overview of diurnal to interannual variabilities in $\mathrm{Hg}^{0}, \mathrm{RGM}$, and $\mathrm{Hg}^{P}$ at locations with distinct geographic and environmental characteristics. This is the first part of a three-part series of papers that are dedicated to detailed analysis of temporal and spatial variations of speciated mercury (Part 1, this study), the relationships between speciated mercury and physical parameters (Part 2, Mao et al., 2012a), and further investigation of key findings from Parts 1 and 2 using potential relationships between speciated mercury and other trace gases (Part 3, Mao et al., 2012b).

\subsection{Measurements and approach}

Observations of $\mathrm{Hg}^{0}$, RGM, and $\mathrm{Hg}^{P}$ were conducted at three AIRMAP (www.airmap.unh.edu) Observatory sites: $\mathrm{TF}\left(43.11^{\circ} \mathrm{N}, 70.95^{\circ} \mathrm{W}, 24 \mathrm{~m}\right.$ a.g.1.), $\mathrm{PM}\left(42.86^{\circ} \mathrm{N}\right.$, $71.88^{\circ} \mathrm{W}, 700 \mathrm{~m}$ a.s.1.), and AI $\left(42.97^{\circ} \mathrm{N}, 70.62^{\circ} \mathrm{W}\right.$, $40 \mathrm{~m}$ a.g.1.) (Fig. 1). The PM and TF sites are 185 and $25 \mathrm{~km}$, respectively, inland from the Atlantic Ocean, while AI is $10 \mathrm{~km}$ offshore in the Gulf of Maine. The locations of the three sites form a unique west-east oriented transect with site surroundings composed of heavily forested, coastal, and marine boundary layer environments. The details with regard to the three locations' sampling setup, land cover, distance to major urban areas, and predominant transport patterns can be found in Mao and Talbot (2004a, b), Talbot et al. (2005), Mao et al. (2008), and Sigler et al. (2009). Moreover, due to the remote central location of PM in New England and its $700 \mathrm{~m}$ elevation (i.e., above the nocturnal 


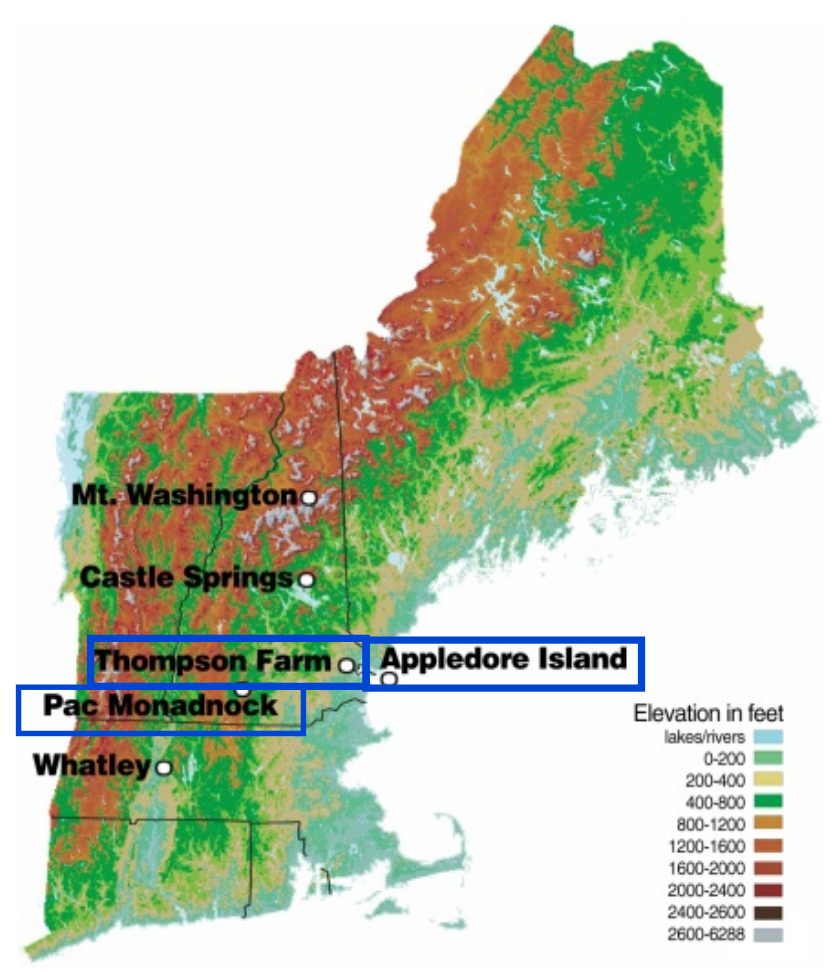

Fig. 1. Locations of the AIRMAP air quality monitoring stations. Thompson Farm, Pac Monadnock, and Appledore Island are highlighted in blue boxes.

inversion and in the middle of the daytime boundary layer), the site is ideally located to determine regional trends in trace gases, including mercury (Mao et al., 2008).

Mercury instruments were operated in an identical manner at TF, PM, and AI to ensure data consistency. Continuous $\mathrm{Hg}^{0}$ measurements with 5-min resolution started from November 2003 at TF, June 2005 at PM, and June 2007 on AI. Measurements of RGM with 2-h resolution were added in November 2006 at TF, December 2006 at PM, and June 2007 on AI. Measurements of $\mathrm{Hg}^{P}$ started at TF in February 2009 and on AI in April 2009. The end date for the study period in this paper for $\mathrm{Hg}^{0}, \mathrm{RGM}$, and $\mathrm{Hg}^{P}$ is 31 August 2010, except that at PM the RGM measurement was terminated in October 2008.

A Tekran 1130 denuder module operated in series with the 2537A provided continuous measurements of $\mathrm{Hg}^{0}$ and semi-continuous data for RGM on a 90 min sampling cycle. A custom cold finger trap was used to remove water vapor before the air stream enters the pump module, which has been used for the entire time periods at TF and PM (Sigler et al., 2009). Ambient mixing ratios of $\mathrm{Hg}^{0}$ were measured continuously, except when RGM and $\mathrm{Hg}^{P}$ were being quantified, using the $2537 \mathrm{~A}$ cold vapor atomic fluorescence spectrometer with 5-min time resolution and a LOD of $\sim 10 \mathrm{ppqv}$ $\left(1 \mathrm{ng} \mathrm{m}^{-3}=112 \mathrm{ppqv}\right)$. Standard additions of $\mathrm{Hg}^{0}$ using the 2537A permeation system were performed twice daily on ambient air during day and night to capture variations in temperature and specific humidity. The system employed an internal permeation tube calibration $( \pm 5 \%$ reproducibility) that was verified every six months using syringe injection from the headspace of a thermoelectrically cooled $\mathrm{Hg}$ reservoir (Tekran model 2505). The precision of the measurements was $\pm 10 \%$ with an accuracy of $\pm 5 \%$. Details of operation of the 2537A can be found in Mao et al. (2008).

RGM is measured with a 90 min sampling interval yielding a LOD of $\sim 0.1 \mathrm{ppqv}$ based on three times the standard deviation of the field blank values determined at $\mathrm{TF}$ during 2007. To ensure clean operation, the $\mathrm{KCl}$-coated denuders, denuder module glassware, impactor frits and sample filters (all prepared in a clean room) are replaced on a biweekly basis. Zero air cartridges and soda lime traps were replaced as needed. Clean operation was verified by flushing of zero air ( $\mathrm{Hg}$-free) through the 1130 denuder module into the 2537A. No direct calibration method has been developed for the Tekran 1130 speciation unit, although thermal desorption and reduction of RGM to $\mathrm{Hg}^{0}$, with subsequent analysis by the $2537 \mathrm{~A}$, is reported to be essentially $100 \%$ efficient (Landis et al., 2002; Sigler et al., 2009). Lyman et al. (2010) reported that an artifact may exist from influence of $\mathrm{O}_{3}$ on Tekran-based RGM measurements. Although we have not tested for this interference, the few high $\mathrm{O}_{3}$ days in New Hampshire during the last decade (Lai et al., 2012) suggests that $\mathrm{O}_{3}$ may have had little influence on our measurements.

The inlet of the Tekran speciation sampling system had an elutriator inlet with an acceleration jet to remove aerosols $>2.5 \mu \mathrm{m}$ so that only fine $\mathrm{Hg}^{P}$ is measured. This is not a desirable design, especially in the marine environment with sea salt in the $2-10 \mu \mathrm{m}$ range. Since our goal was to elucidate mercury cycling, the total amount of mercury in the aerosol phase must be determined accurately. We replaced the elutriator for the instruments at $\mathrm{TF}$ and $\mathrm{AI}$ with one that contained no impaction plate to facilitate collection of coarse aerosols on the quartz frit in the Tekran 1135 (Talbot et al., 2011). This produced satisfactory results on average when compared to bulk collection on a Teflon filter, except when $\mathrm{Hg}^{P}$ values were above 1 ppqv (Talbot et al., 2011). In these cases the Tekran underestimated $\mathrm{Hg}^{P}$ by as much as a factor of 3 . At PM which is far from the ocean, the speciation system was operated in the standard configuration.

Measurement data of carbon monoxide (CO) were used in this study in determining anthropogenic influence. A description of $\mathrm{CO}$ measurement can be found in Mao and Talbot (2004b). Carbon monoxide is an excellent anthropogenic tracer because it mostly comes from mobile combustion. Air masses with $\mathrm{CO}$ mixing ratios below the 25 th percentile value are commonly considered background air. Hence we selected 5-min average $\mathrm{CO}$ data below the monthly 25 th percentile value to represent the background atmosphere. From this subset of data, the background $\mathrm{Hg}^{0}$ levels were estimated from monthly median mixing ratios of $\mathrm{Hg}^{0}$. 
Table 1. The total decrease and increase (ppqv) of $\mathrm{Hg}^{0}$ as well as its decline and increase rates (ppqv $\mathrm{d}^{-1} \pm$ standard error, in parentheses) during the warm and cool seasons at AI, TF, and PM. The asterisks denote the seasons that were shorter due to missing measurement data and/or shortened study periods. The mean values and ranges did not include the values with asterisks.

\begin{tabular}{|c|c|c|c|c|c|c|}
\hline & \multicolumn{2}{|c|}{ AI } & \multicolumn{2}{|c|}{$\mathrm{TF}$} & \multicolumn{2}{|c|}{ PM } \\
\hline & warm & cool & warm & cool & warm & cool \\
\hline 2004 & - & - & $\begin{array}{l}-44 \\
(-0.2 \pm 0.002)\end{array}$ & $\begin{array}{l}54 \\
(0.5 \pm 0.003)\end{array}$ & - & - \\
\hline 2005 & - & - & $\begin{array}{l}-92 \\
(-0.6 \pm 0.002)\end{array}$ & $\begin{array}{l}69 \\
(0.5 \pm 0.003)\end{array}$ & $\begin{array}{l}-36 \\
(-0.2 \pm 0.002)\end{array}$ & $\begin{array}{l}19 \\
(0.1 \pm 0.002)\end{array}$ \\
\hline 2006 & - & - & $\begin{array}{l}-62 \\
(-0.4 \pm 0.003)\end{array}$ & $\begin{array}{l}56 \\
(0.4 \pm 0.003)\end{array}$ & $\begin{array}{l}-47 \\
(-0.2 \pm 0.002)\end{array}$ & $\begin{array}{l}39 \\
(0.3 \pm 0.002)\end{array}$ \\
\hline 2007 & $\begin{array}{l}-84^{* 1} \\
(-0.8 \pm 0.005)\end{array}$ & - & $\begin{array}{l}-62 \\
(-0.4 \pm 0.002)\end{array}$ & $\begin{array}{l}53 \\
(0.4 \pm 0.004)\end{array}$ & $\begin{array}{l}-49 \\
(-0.2 \pm 0.001)\end{array}$ & $\begin{array}{l}37 \\
(0.3 \pm 0.002)\end{array}$ \\
\hline 2008 & $\begin{array}{l}-18 \\
(-0.1 \pm 0.003)\end{array}$ & $\begin{array}{l}55 \\
(0.3 \pm 0.003)\end{array}$ & $\begin{array}{l}-48 \\
(-0.3 \pm 0.002)\end{array}$ & $\begin{array}{l}52 \\
(0.4 \pm 0.004)\end{array}$ & $\begin{array}{l}-30 \\
(-0.1 \pm 0.001)\end{array}$ & $\begin{array}{l}20 \\
(0.3 \pm 0.003)\end{array}$ \\
\hline 2009 & $\begin{array}{l}-45 \\
(-0.2 \pm 0.001)\end{array}$ & $\begin{array}{l}50 \\
(0.3 \pm 0.004)\end{array}$ & $\begin{array}{l}-43 \\
(-0.3 \pm 0.002)\end{array}$ & $\begin{array}{l}52 \\
(0.4 \pm 0.002)\end{array}$ & $\begin{array}{l}-32 \\
(-0.1 \pm 0.001)\end{array}$ & $\begin{array}{l}32 * 5 \\
(0.5 \pm 0.003)\end{array}$ \\
\hline 2010 & $\begin{array}{l}-48^{* 2} \\
(-0.3 \pm 0.003)\end{array}$ & - & $\begin{array}{l}-11^{* 3} \\
(-0.1 \pm 0.003)\end{array}$ & - & $\begin{array}{l}-24^{* 4} \\
(-0.2 \pm 0.001)\end{array}$ & - \\
\hline Mean & $\begin{array}{l}-32 \\
(-0.2 \pm 0.002)\end{array}$ & $\begin{array}{l}53 \\
(0.3 \pm 0.004)\end{array}$ & $\begin{array}{l}-59 \\
(-0.4 \pm 0.002)\end{array}$ & $\begin{array}{l}56 \\
(0.4 \pm 0.003)\end{array}$ & $\begin{array}{l}-39 \\
(-0.2 \pm 0.001)\end{array}$ & $\begin{array}{l}30 \\
(0.3 \pm 0.002)\end{array}$ \\
\hline Range & $\begin{array}{l}-45--18 \\
(-0.1--0.2)\end{array}$ & $\begin{array}{l}50-55 \\
(0.3)\end{array}$ & $\begin{array}{l}-92--43 \\
(-0.2--0.6)\end{array}$ & $\begin{array}{l}52-69 \\
(0.4-0.5)\end{array}$ & $\begin{array}{l}-30--49 \\
(-0.1--0.2)\end{array}$ & $\begin{array}{l}19-39 \\
(0.1-0.3)\end{array}$ \\
\hline
\end{tabular}

${ }^{1}$ Measurements at AI started on 7 June 2007, making the 2007 warm season about three months shorter than a regular warm season. $2,3,4$ The study period ended on 31 August 2010, making the 2010 warm season about two months shorter than a regular warm season. ${ }^{5}$ Only two and half months of data were available for the 2009 cool season.

\section{$2 \mathrm{Hg}^{0}$, RGM, and $\mathrm{Hg}^{P}$ at marine, coastal and inland sites}

\subsection{Seasonal and annual variations}

The complete time series of 5-min average $\mathrm{Hg}^{0}$ mixing ratios for the time periods of availability at AI, TF, and PM are displayed in Fig. 2. The 7.5, 5.5, and $\sim 3$ yr datasets at TF, PM, and AI, respectively, reproduced the annual cycle with a maximum in late winter - early spring and a minimum in early fall as identified in Mao et al. (2008). Note that the large enhancements at PM during the time period of May-October 2009 were data contaminated by local sources, which were removed in our analysis. In the extended dataset presented here, TF consistently exhibited strong day-to-day variation with low values reaching $\sim 50$ ppqv in early fall and the highest levels exceeding 300 ppqv in late winter - early spring. The three years of data at AI suggested clearly that trends at AI tracked those at TF well, although the diurnal minimum did not plunge to the low levels at TF and the diurnal maximum often exceeded that at TF. In comparison, $\mathrm{Hg}^{0}$ at the elevated rural inland site, PM, revealed much smaller diurnal-to-annual variations and much higher minimum values. At PM spikes rarely exceeded 250 ppqv while the dips were typically $\sim 100$ ppqv, consistent with Mao et al. (2008).

One distinct feature that set TF apart from AI and PM was the lowest levels of $\mathrm{Hg}^{0}$ ( $<50$ ppqv), which occurred in sum- mer and fall and was suggested to be due to dry deposition of $\mathrm{Hg}^{0}$ under the nocturnal inversion layer by Mao et al. (2008). A comparison of $\mathrm{Hg}^{0}$ seasonal statistics at the three sites is shown in Fig. 3 and is summarized in Table S1 in the Supplement. One striking feature is that the lowest 10th percentile values at TF in summer and fall were lower than PM by 1144 ppqv over the period from 2004 to 2010 except the fall of 2009 when the 10th percentile value at PM (94 ppqv) was close to that at TF (95 ppqv). The 10th percentile values at AI were $\sim 110$ ppqv for the three summers (2007-2009), lower than PM by 10-20 ppqv, whereas it rose to 128 ppqv at $\mathrm{AI}$ in summer 2010, close to that at PM. Winter and spring median values from TF and PM were in close range (within 10 ppqv) nearly all years except 2009 when values at TF were 2030 ppqv higher. At AI, the springtime median level was lower by $>10$ ppqv than those at TF and PM in 2008, close to that at PM but lower by 15 ppqv than the value at TF in 2009 , and higher by $\sim 20$ ppqv than the values at both TF and PM in 2010. Overall, there seemed to lack a general pattern of spatial variability in these metrics at the three locations.

The decline and increase rates of $\mathrm{Hg}^{0}$ in the warm and cool seasons, respectively, were calculated and examined for the three sites (Table 1). The warm season spans the time period between the times of the annual maximum and minimum, approximately 1 April to 30 September at TF, 1 March to 31 October at AI, and 1 March to 31 October at PM. The cool season extends from the time of the annual minimum to 


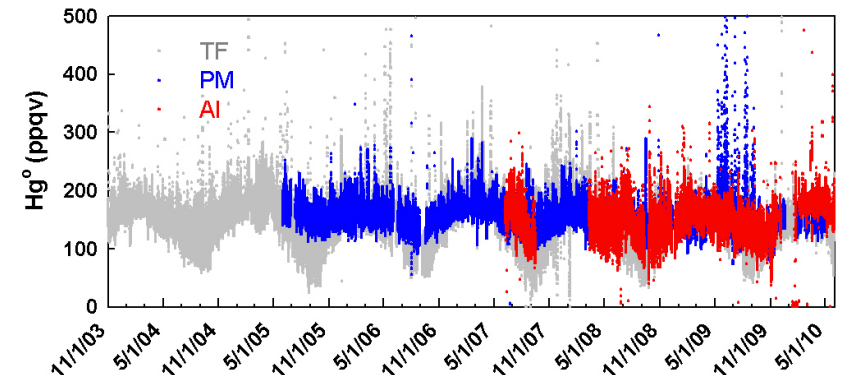

Fig. 2. Complete time series of 5-min average $\mathrm{Hg}^{0}$ at Thompson Farm (TF) (gray), Pac Monadnock (PM) (blue), and Appledore Island (AI) (red). Large enhancements at PM during the time period of May-October 2009 were data contaminated by local sources, which were removed in analysis.

that of the following annual maximum. In other words, the warm and cool seasons correspond to the growth and senescence seasons. The rates were calculated based on the slope values of the linear trend that was fitted through all the data points for the two seasons each year. The rates of decline and increase in the warm and cool season, respectively, were employed to quantify interannual variability and site differences in the annual cycle. A few main characteristics can be summarized as follows.

First, there was much less year-to-year variability in the cool season increase rate at all three sites compared to the warm season decline rates. Total seasonal increases for cool seasons with nearly complete data samples averaged 53 ppqv at $\mathrm{AI}$ (50-55 ppqv), 56 ppqv (52-69 ppqv) at TF, and 30 ppqv (19-39 ppqv) at PM, suggesting greater values at $\mathrm{AI}$ and TF than at PM. Rates of increase averaged $0.3 \mathrm{ppqv}$ day $^{-1}$ at AI, 0.4 ppqv day $^{-1}$ at TF, and 0.3 ppqv day $^{-1}(0.1-$ 0.3 ppqv day $^{-1}$ ) at PM, yielding comparable rates at the three sites. A closer look revealed that during the 2008 cool season, $\mathrm{Hg}^{0}$ levels at PM reached the annual maximum in midDecember as opposed to the end of February as in other years, which resulted in an average rate of increase albeit with the lowest total increase and shortest cool season of all five years. The highest rate of increase in 2009 at PM should be taken with caution because the measurement data was available through mid-December 2009 only.

One striking feature was that mixing ratios of $\mathrm{Hg}^{0}$ in the marine (AI) and coastal (TF) environments increased more than at a rural elevated location (PM) during the cool season. This indicates that as the cool season started in late September and early October, sinks may be reduced and/or sources enhanced in the marine (AI) and coastal (TF) environments more strongly than at a remote site like PM. During that time of the year enhanced sources are likely associated with coal and natural gas combustion as well as wood burning for residential heating in the region. Weakened sinks could be linked to plant senescence, which reduces the surface area for $\mathrm{Hg}^{0}$ uptake, as well as snow cover for which dry deposition ve-

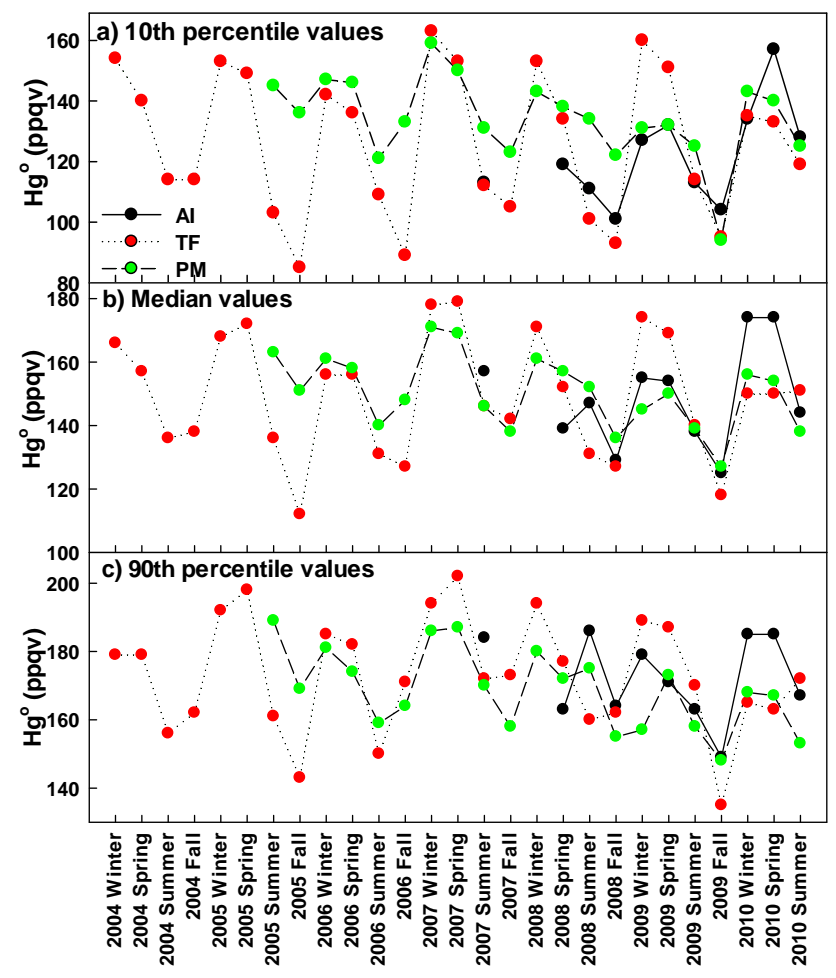

Fig. 3. Seasonal 10th percentile (a), median (b), and 90th percentile (c) mixing ratios of $\mathrm{Hg}^{0}$ at $\mathrm{AI}$ (black), TF (red), and PM (green).

locities of $\mathrm{Hg}^{0}$ are two to four orders of magnitude smaller than for other surface types (Zhang et al., 2009, and references therein). The slower rate of increase at PM may reflect its relatively remote location and higher altitude where anthropogenic influence is dampened compared to $\mathrm{AI}$ and $\mathrm{TF}$ that are closer to source regions.

Second, the decline rate of $\mathrm{Hg}^{0}$ during warm seasons at TF varied greatly from year to year compared to relatively small ranges at AI and PM with some exceptions. Specifically, excluding the seasons with more than 2 months of missing data $(\sim 30 \%$ of the total measurement data), the rate of decline at $\mathrm{AI}$ and PM ranged from $-0.2 \mathrm{ppqv} \mathrm{day}^{-1}$ to $-0.1 \mathrm{ppqv}^{-1} \mathrm{day}^{-1}$, whereas at TF it ranged from $-0.6 \mathrm{ppqv}$ day $^{-1}$ to -0.2 ppqv day $^{-1}$. At TF, the maximum warm season decline rate of -0.6 ppqv day ${ }^{-1}$ occurred in 2005 yielding a total seasonal loss of $92 \mathrm{ppqv}$, while the minimum rate of -0.2 ppqv day ${ }^{-1}$ resulted in a total decrease (in a complete warm season) of 43 ppqv in 2009. This suggests that at TF there were unique processes that set its warm season decline rates apart from the other two environments. Mao et al. (2008) identified two warm seasons in 2004 and 2005 with drastically different decline rates of $\mathrm{Hg}^{0}$ at $\mathrm{TF}$ and speculated that the large difference in precipitation from 2004 to 2005 observed at the site may have been the main cause. At the time there were barely two years of data at PM over 20052007 which could not be compared with the two contrasting seasons at TF. In this study as the 5.5-yr dataset at PM 

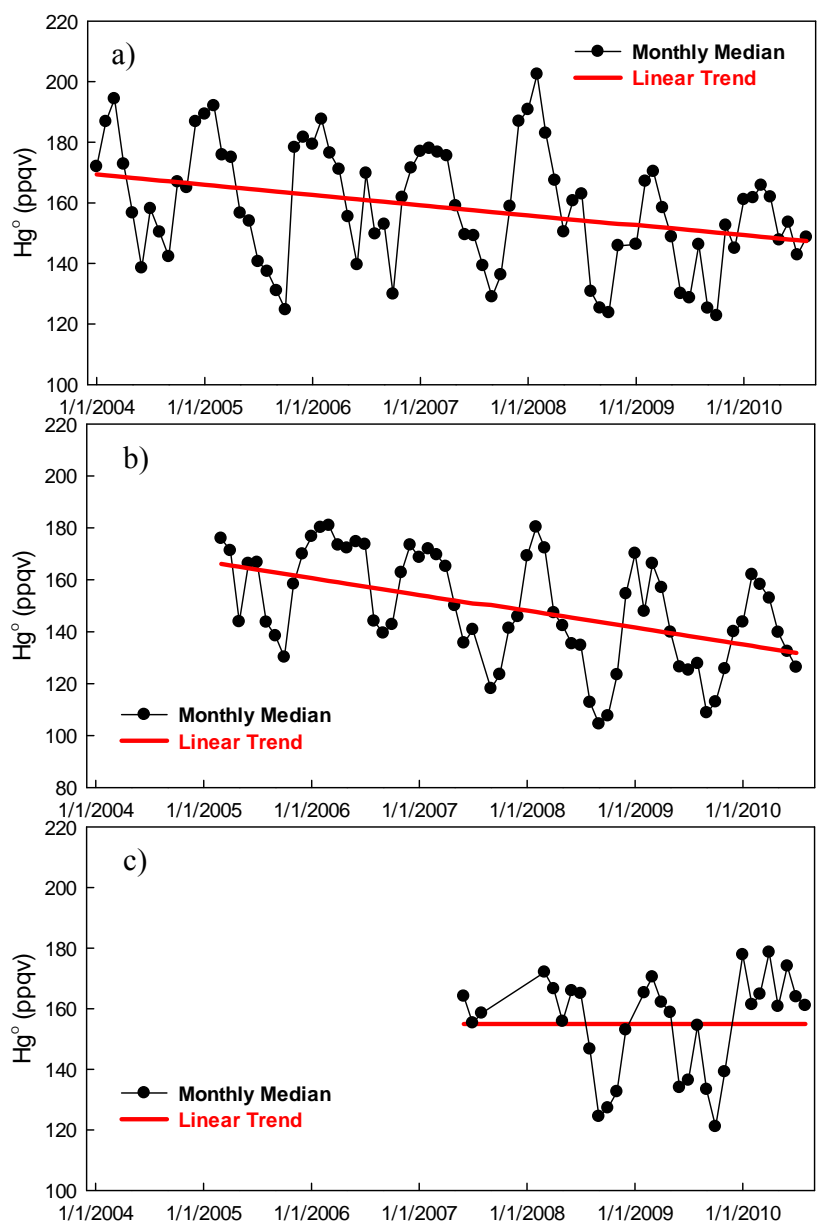

Fig. 4. Monthly median mixing ratios of background $\mathrm{Hg}^{0}$ at Thompson Farm (TF) (a) Pac Monadnock (PM) (b), Appledore Island $(\mathrm{AI})(\mathbf{c})$.

from 2005 to 2010 was examined, unlike TF, the 2005 warm season decline rate at PM did not appear to stand out as an anomaly. Our previous studies demonstrated that measurements at PM are representative of regional air pollution (Mao and Talbot, 2004; Mao et al., 2008), and therefore the peak decline rate at TF during the 2005 warm season appeared to be a localized phenomenon instead of a regional one. Indeed, the reports from the Northeastern Regional Climate Center (http://www.nrcc.cornell.edu/) suggested that the 2005 spring in New Hampshire was a normal spring and the summer was warmer and wetter, but not to the extreme, regarding temperature and precipitation in the context of the $116 \mathrm{yr}$ climate record. Summers 2006, 2008, and 2009 were among the wettest on record, and yet the warm season decline rates during those three years were average. In-depth study is warranted to understand and identify the mechanism(s) driving the decline/increasing patterns as well as the year-to-year variability in such patterns.

The overall trends in background $\mathrm{Hg}^{0}$ at the three sites were examined in Fig. 4. There appeared to be decreasing

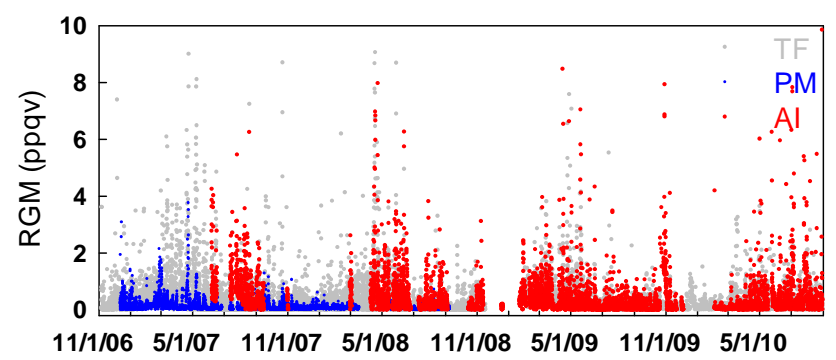

Fig. 5. Complete time series of 2-hourly RGM mixing ratios at Thompson Farm (TF), Pac Monadnock (PM), and Appledore Island (AI).

trends in background $\mathrm{Hg}^{0}$ at $\mathrm{TF}$ and PM with decline rates of

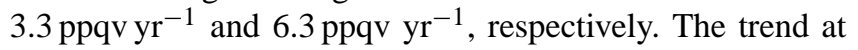
AI was inconclusive because of a limited number of years of measurements. The Student's $t$-test from Wilks (1995) was used to test the statistical significance of the trends. For the TF site, the $t$-value was -3.05 , exceeding the critical $t$-value of 1.664 for a one-sided t-distribution at the $95 \%$ confidence level. For the 64 monthly median background $\mathrm{Hg}^{0}$ mixing ratios at Pack Monadnock, the t-value was 4.344, exceeding the critical t-value of 1.671 for a one-sided t-distribution at the $95 \%$ confidence level. Therefore, the decline trends at the two sites are statistically significant.

These declining trends suggest that in an elevated rural environment, which is above the boundary layer half of the time (i.e., at night), background $\mathrm{Hg}^{0}$ mixing ratios were decreasing at a pace nearly a factor of 2 faster than that at the coastal site TF, although the time period of the TF dataset was $1.3 \mathrm{yr}$ longer than the PM one. For the overlapping 5.5 year period at $\mathrm{TF}$ and $\mathrm{PM}$, the slope value of the regression line was

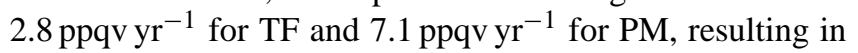
a total decrease of 16 ppqv and 38 ppqv for TF and PM, respectively. The decline rate at $\mathrm{TF}$ was comparable to the ones from Mace Head, Ireland (Ebinghaus et al., 2011) and Cape Point, South Africa (Slemr et al., 2011), while caution should be taken in such comparison as the time periods in Ebinghaus et al. (2011) and Slemr et al. (2011) were nearly twice as long as ours. We will investigate the possible factors that might have contributed to these trends in a separate paper (Mao et al., 2012).

The complete time series of RGM exhibited distinct annual cycles in the occurrence of higher mixing ratios at TF and AI as shown in Fig. 5. The seasonal statistics are summarized in Table 2, where the asterisked numbers represent seasons with measurements missing consecutively over more than half a season, and thus these numbers were not considered in the comparison. At TF the annual cycles in the median and 90th percentile RGM levels displayed a maximum in spring and a minimum in fall. At AI the annual cycles of the median and 90th percentile values were not conclusive because the fall and winter time periods had a large amount of data missing; the relatively complete datasets in springs 
Table 2. The lower 10th, median and 90th percentile values of RGM (ppqv) at AI, TF, and PM. N stands for the total number of samples. The asterisked sample numbers stand for seasons with measurements missing consecutively for half of the season.

\begin{tabular}{|c|c|c|c|c|c|c|c|c|c|c|c|c|}
\hline & \multicolumn{4}{|c|}{$\mathrm{AI}$} & \multicolumn{4}{|c|}{$\mathrm{TF}$} & \multicolumn{4}{|c|}{ PM } \\
\hline & $N$ & 10th & Med & 90th & $N$ & 10th & Med & 90th & $N$ & 10th & Med & 90th \\
\hline 2006 11/6-30 & & & & & 276 & 0.00 & 0.03 & 0.34 & & & & \\
\hline 2007 Winter & & & & & 925 & 0.06 & 0.24 & 0.87 & 635 & 0.06 & 0.16 & 0.54 \\
\hline Spring & & & & & 865 & 0.12 & 0.55 & 2.48 & 843 & 0.02 & 0.14 & 0.57 \\
\hline Summer & 507 & 0.18 & 0.55 & 1.72 & 469 & 0.07 & 0.26 & 1.00 & 586 & 0.01 & 0.04 & 0.19 \\
\hline Fall & *143 & 0.06 & 0.28 & 1.03 & 578 & 0.07 & 0.21 & 0.80 & 681 & 0.01 & 0.04 & 0.26 \\
\hline 2008 Winter & - & - & - & - & 671 & 0.08 & 0.20 & 0.59 & 943 & 0.01 & 0.03 & 0.12 \\
\hline Spring & 439 & 0.07 & 0.50 & 1.92 & 733 & 0.10 & 0.35 & 1.57 & 347 & 0.01 & 0.05 & 0.22 \\
\hline Summer & 635 & 0.05 & 0.21 & 1.16 & *299 & 0.00 & 0.12 & 0.65 & 717 & 0.00 & 0.02 & 0.10 \\
\hline Fall & $* 253$ & 0.02 & 0.13 & 0.58 & 302 & 0.05 & 0.14 & 0.59 & & & & \\
\hline 2009 Winter & 333 & 0.12 & 0.36 & 0.92 & $* 220$ & 0.17 & 0.42 & 0.97 & & & & \\
\hline Spring & 584 & 0.10 & 0.37 & 1.34 & 652 & 0.08 & 0.41 & 1.52 & & & & \\
\hline Summer & 306 & 0.07 & 0.21 & 0.78 & 594 & 0.04 & 0.13 & 0.43 & & & & \\
\hline Fall & $* 279$ & 0.08 & 0.29 & 1.63 & 428 & 0.03 & 0.09 & 0.30 & & & & \\
\hline 2010 Winter & $* 206$ & 0.01 & 0.03 & 0.09 & 401 & 0.03 & 0.09 & 0.37 & & & & \\
\hline Spring & 518 & 0.02 & 0.14 & 0.78 & 514 & 0.04 & 0.16 & 0.94 & & & & \\
\hline Summer & 609 & 0.06 & 0.23 & 1.43 & 537 & 0.02 & 0.10 & 0.70 & & & & \\
\hline
\end{tabular}

and summers suggested values close to their counterparts at the coastal site TF. At the inland site PM, the 10th percentile and median values were below the LOD (0.1 ppqv) in nearly all seasons. The median values in winter and spring 2007 at $\mathrm{PM}$ and the 90th percentile mixing ratios were at or above the LOD (Table 2).

Three key points can be summarized regarding the 10th percentile, median, and 90th percentile values. First, a common characteristic in RGM at the marine, coastal, and inland sites is near-zero 10th percentile values. Second, RGM mixing ratios were generally lowest at PM, with median values and 90th percentile values hardly exceeding $0.5 \mathrm{ppqv}$ throughout the 7 seasons, even though two coal-fired power plants are located nearby, Salem Harbor and Merrimack Stations $168 \mathrm{~km}$ south and $119 \mathrm{~km}$ north of PM, respectively. This is consistent with observations from other geographic locations, such as the site on the eastern slope of Mt. Gongga in China (Fu et al., 2008) with two industrial areas located $50-60 \mathrm{~km}$ south and southeast of the sampling site, where RGM is lost relatively fast via dry deposition after leaving its sources. Third, larger median and 90th percentile mixing ratios were observed in the marine environment than at the coastal and inland locations in all seasons except springs 2009 and 2010 when the 90th percentile values at TF were slightly higher. The last point indicates stronger source strength(s) for RGM in the marine environment, which alludes to the possibility of more $\mathrm{Hg}^{0}$ oxidized by abundant halogen radicals there leading to higher RGM mixing ratios.

Mixing ratios of $\mathrm{Hg}^{P}$ at $\mathrm{AI}$ and $\mathrm{TF}$ were close in magnitude to RGM levels. They were mostly below 1 ppqv except for the data points exceeding the 90th percentile value in February-May 2009 at TF as well as in fall 2009 at AI

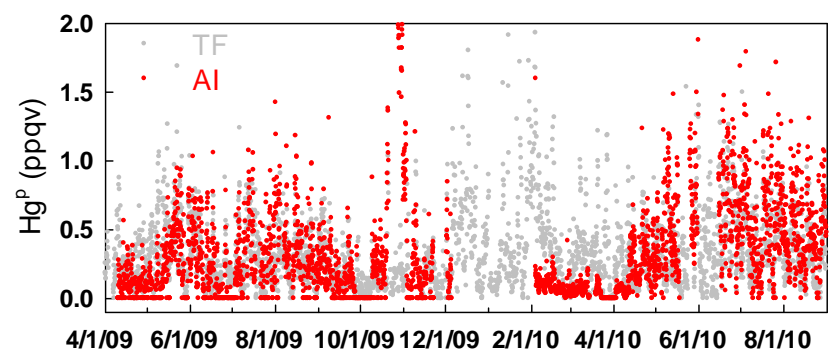

Fig. 6. Complete time series of 2-hourly $\mathrm{Hg}^{P}$ at Appledore Island (AI) and Thompson Farm (TF).

for reasons not readily apparent (Fig. 6 and Table 3). Observations at TF revealed that the annual maximum occurred in winter and minimum in fall, which is similar to the annual cycle of RGM. This appears to be reasonable owing to two factors. First, maximum RGM in late winter/early spring makes it possible for maximum conversion of RGM to $\mathrm{Hg}^{P}$ via deposition to aerosol surfaces. Second, the strong temperature dependence of gas-particle partitioning would be conducive to higher $\mathrm{Hg}^{P}$ levels in winter than in other seasons (Rutter et al., 2008; Amos et al., 2012).

\subsection{Diurnal variation}

\subsection{1 $\mathbf{H g}^{0}$}

Our previous study (Mao et al., 2008) using 3 and 2 yr of $\mathrm{Hg}^{0}$ measurements data at TF and PM, respectively, revealed that the largest diurnal variability occurs in the fall at TF with a seasonal averaged daily amplitude of $\sim 20$ ppqv, whereas 
(a)

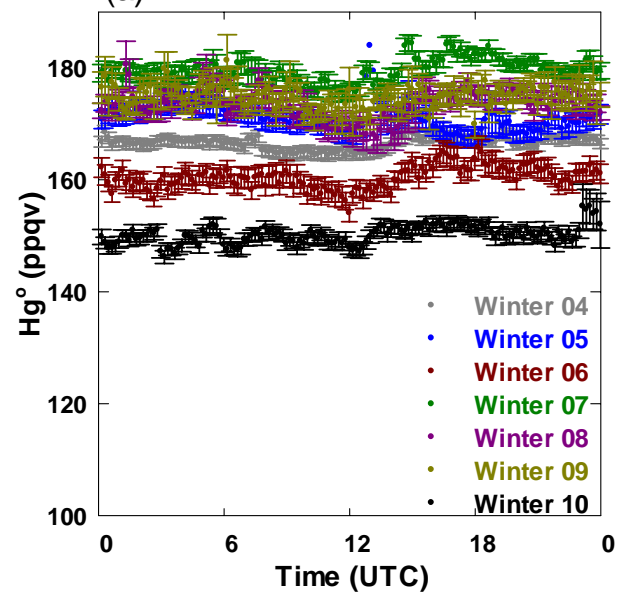

(b)

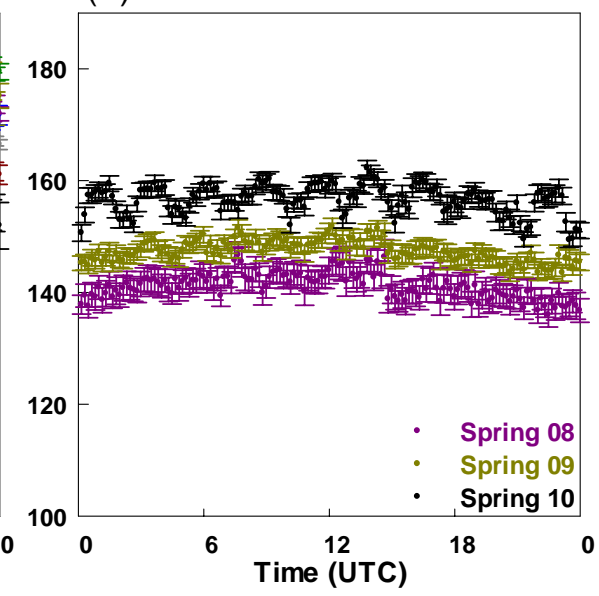

Fig. 7. Seasonally averaged diurnal cycles of $\mathrm{Hg}^{0}$ with standard deviation of means for summer at $\mathrm{TF}$ (a) and AI (b).

the diurnal variation at PM was flat year-round except in the 2006 summer with a seasonal averaged daily amplitude of $\sim 10$ ppqv. In this study, the 7.5-yr dataset suggested that seasonal variation in the $\mathrm{Hg}^{0}$ diurnal pattern was reproduced unfailingly every year at the three sites, and in some seasons there was remarkable interannual variability in the $\mathrm{Hg}^{0}$ diurnal pattern depending on site location. At TF, the diurnal variation was nearly flat in all 7 winters followed by increases to a daily amplitude of $\sim 10-20$ ppqv in spring and was most pronounced in summer (Fig. 7a) and fall with a daily amplitude ranging from 20 to $40 \mathrm{ppqv}$. The daily minimum occurred before sunrise and the maximum at $\sim 14: 00$ UTC in spring and $\sim 15: 00$ UTC in summer and fall.

As suggested in Mao et al. (2008), nighttime low mixing ratios of $\mathrm{Hg}^{0}$ at $\mathrm{TF}$ in the warm season resulted from the occurrence of the nocturnal inversion at altitudes below $\sim 300 \mathrm{~m}$ in New England. A box modeling study by Kim (2010) found that using the Henry's Law coefficient of $0.13 \mathrm{M} \mathrm{atm}^{-1}$ for $\mathrm{Hg}^{0}$ and initial conditions of $170 \mathrm{ppqv}$ $\mathrm{Hg}^{0}, 25^{\circ} \mathrm{C}$ temperature, and liquid water content of $10^{-10}$ $\left(\mathrm{m}_{\text {water }}^{3} / \mathrm{m}_{\text {air }}^{3}\right)$, the atmospheric mixing ratio of $\mathrm{Hg}^{0}$ decreased from $170 \mathrm{ppqv}$ to zero after $30 \mathrm{~h}$. On summer nights when a nocturnal inversion layer formed at $\mathrm{TF}$, often the $\mathrm{Hg}^{0}$ mixing ratio was observed to decrease from 120 ppqv to 80 ppqv over $10 \mathrm{~h}$ on average reaching its minimum value just before sunrise. On those nights there was abundant dew formation due to radiative cooling at the surface; should the same amount of dew remain for 20 more hours and the $\mathrm{Hg}^{0}$ level continue to decrease at the same rate, the atmospheric $\mathrm{Hg}^{0}$ level could be reduced to zero. Since this estimate is close to box model results from Kim et al. (2010), it is hypothesized that the observed nighttime depletion of $\mathrm{Hg}^{0}$ is caused by $\mathrm{Hg}^{0}$ dissolving into dew. The fate of dissolved $\mathrm{Hg}^{0}$ is unknown at present. One possibility is that the observed 40 ppqv $\mathrm{Hg}^{0}$ dissolved in dew would largely be revolatilized after sunrise, and thus the increase in $\mathrm{Hg}^{0}$ mix- ing ratios between sunrise and 15:00 UTC in summer could be ascribed chiefly to $\mathrm{Hg}^{0}$ re-volatilization from dew alone. Other possibilities could be more permanent sequestration of the deposited $\mathrm{Hg}$ due to heterogeneous and aqueous processes (e.g., $\mathrm{O}_{3}$ induced oxidation; c.f., Subir et al., 2011, 2012).

From the $\sim 3$-yr dataset at AI emerged one of the most interesting characteristics in the diurnal variation of $\mathrm{Hg}^{0}$ in the summertime marine boundary layer (Fig. 7b). It is opposite in phase to that at $\mathrm{TF}$, with daily maxima before sunrise and minima in the time window of 20:00-00:00 UTC. There appeared to be a net loss of $\mathrm{Hg}^{0}$ around $10 \mathrm{ppqv}$ during the day at AI (daily maximum-minimum). This was also documented in Sigler et al. (2009) where a 2-month dataset in July-September 2007 suggested opposite diurnal cycles of $\mathrm{Hg}^{0}$ and RGM at AI. This pattern was reproduced in summers 2008, 2009 and 2010 with nearly identical patterns and magnitude (Fig. 7b). We speculated that the net loss of $\mathrm{Hg}^{0}$ during the day was possibly caused by oxidation by abundant halogen radicals in the marine boundary layer (Sigler et al., 2009).

Compared to TF and AI, diurnal variation at PM appeared to be nearly flat in all seasons except summers 2006 and 2009 with a seasonally averaged daily amplitude of $10 \mathrm{ppqv}$ (not shown). The seasonal variation in the diurnal amplitude was relatively small, constrained within 20 ppqv in all five years. This lack of diurnal, seasonal and annual variation was attributed to its $700 \mathrm{~m}$ a.s.l. elevation, well above the nighttime boundary layer and thus the site is removed from direct influence of chemical and physical processes near the surface (Mao et al., 2008). Moreover, the winter and spring level at $\mathrm{PM}$ is close to that at TF and AI, reflecting the regional representativeness of the site, whereas in summer and fall it tended to be $20-30$ ppqv higher indicating additional $\operatorname{sink}(\mathrm{s})$ at TF and AI. Compared to TF and AI, the standard deviation of means at PM appeared to be much smaller, indicating that 
Table 3. The 10th, 50th, and 90th percentile values (ppqv) of $\mathrm{Hg}^{P}$ at TF and AI.

\begin{tabular}{l|llll|llll}
\hline & \multicolumn{4}{|c|}{ TF } & \multicolumn{5}{c}{ AI } \\
\hline & $N$ & 10th & Med & 90th & $N$ & 10th & Med & 90th \\
\hline 2009 February & 220 & 0.43 & 0.88 & 1.71 & & & & \\
Spring & 634 & 0.12 & 0.36 & 1.14 & 290 & 0.07 & 0.19 & 0.55 \\
Summer & 660 & 0.09 & 0.25 & 0.57 & 489 & 0.10 & 0.33 & 0.73 \\
Fall & 461 & 0.06 & 0.15 & 0.41 & 400 & 0.09 & 0.25 & 1.27 \\
2010 Winter & 451 & 0.08 & 0.39 & 0.98 & 237 & 0.04 & 0.09 & 0.20 \\
Spring & 579 & 0.08 & 0.26 & 0.59 & 566 & 0.03 & 0.21 & 0.81 \\
Summer & 694 & 0.09 & 0.35 & 0.77 & 691 & 0.16 & 0.52 & 0.98 \\
\hline
\end{tabular}

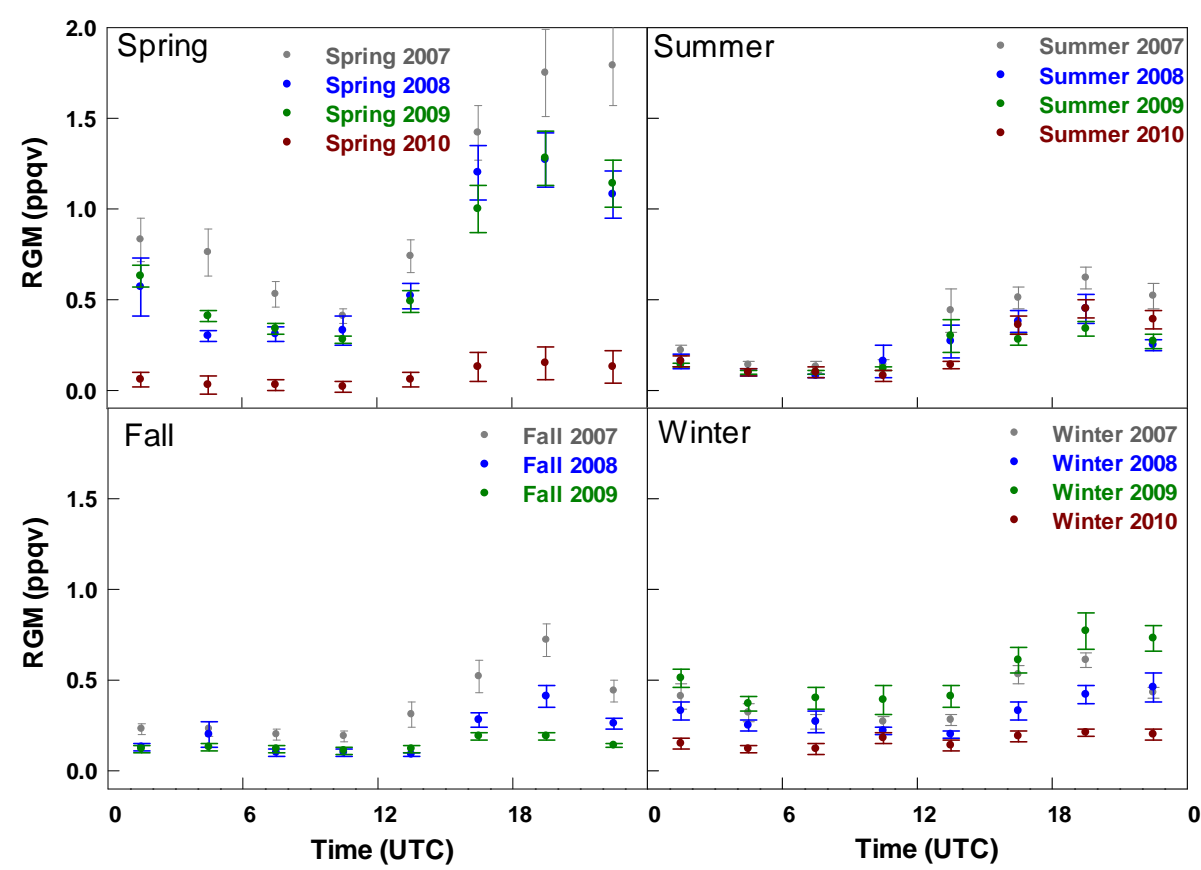

Fig. 8. Seasonally averaged diurnal cycles of RGM with standard deviation of means at TF.

at this elevated inland rural site there were less disturbances on time scales $<10 \mathrm{~min}$ that could bring about changes in ambient levels of $\mathrm{Hg}^{0}$ than in the coastal and marine environments.

Two interesting features were apparent in interannual variability of seasonal averaged diurnal cycles at the three sites. First, among the three sites, TF experienced the most significant interannual variability in winter, spring, and fall diurnal cycles compared to the least amount at $\mathrm{AI}$ and $\mathrm{PM}$ constrained within $\sim 20$ ppqv (not shown). It should be mentioned that at $\mathrm{AI} \mathrm{Hg}{ }^{0}$ levels in fall 2007 were nearly 30 ppqv lower than the other two years due to limited data availability during 1-16 September reflecting the lowest level of $\mathrm{Hg}^{0}$ in the year (not shown). Second, both TF and AI exhibited the least interannual variability in summer compared to other seasons, whereas PM exhibited reversed seasonal dependence of interannual variability (not shown). This raises the question whether such site differences reflect the effects of marine-land or altitude difference, which can entail profound implications. Interannual variability in $\mathrm{Hg}^{0}$ can result from influences of anthropogenic emissions, physical processes (i.e., driven by climate conditions), and chemistry. Hence, the site differences may suggest that at elevated inland rural locations, interannual variability in ambient levels of $\mathrm{Hg}^{0}$ is largely driven by processes in summer, whereas in the coastal and marine environments downwind of major source regions the net effect of all processes can vary greatly from year to year in all seasons except summer.

\subsubsection{RGM}

There was distinct diurnal variation at $\mathrm{TF}$ and $\mathrm{AI}$ with maxima at 18:00-20:00 UTC and minima at 09:00-11:00 UTC (Figs. 8 and 9), whereas it was almost flat at PM and near the LOD in all seasons except spring and winter 2007 (not 


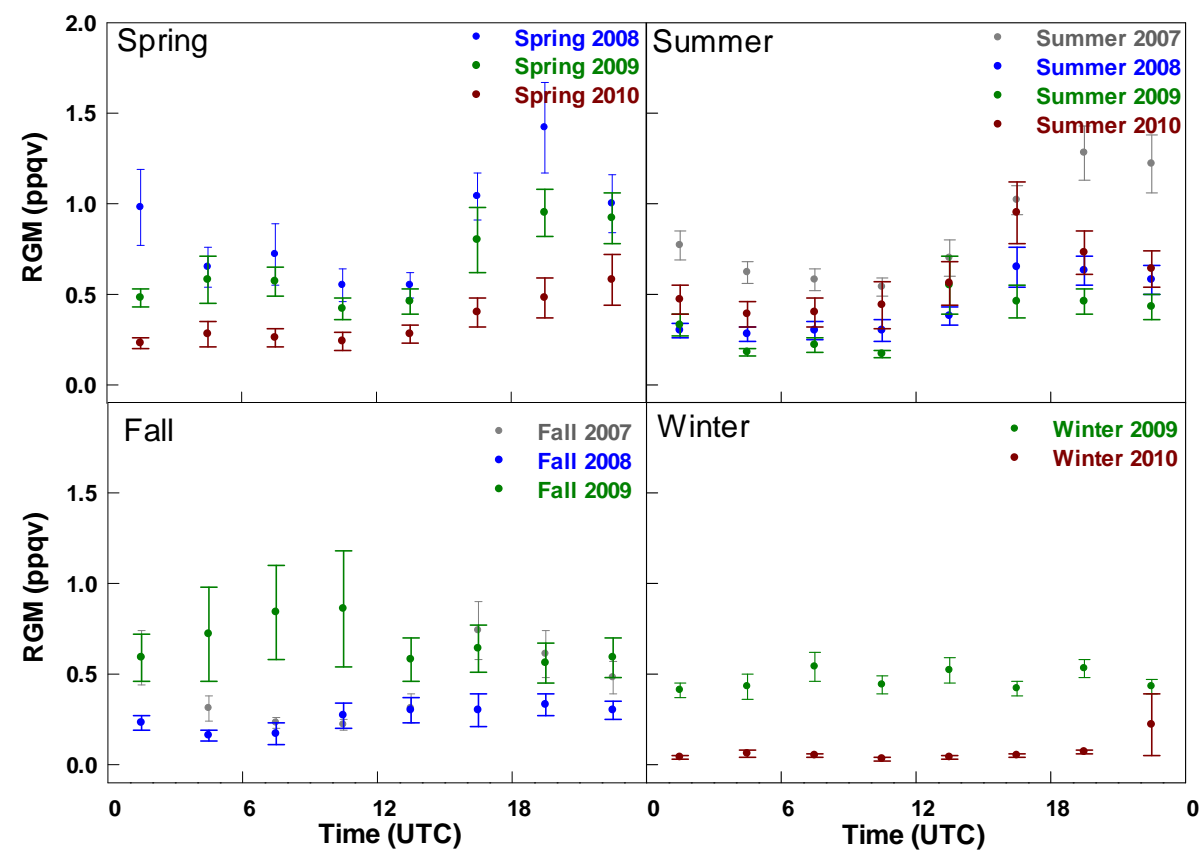

Fig. 9. Seasonally averaged diurnal cycles of RGM with standard deviation of means at AI.

shown). The strongest diurnal variation occurred in springs 2007, 2008, and 2009 at TF, with daily amplitude exceeding $1 \mathrm{ppqv}$ compared to $0.2-0.3 \mathrm{ppqv}$ in other seasons. The highest seasonal average diurnal maxima also occurred in the same seasons reaching up to $1.7 \mathrm{ppqv}$, while daily maxima varied between the LOD and 0.7 ppqv in all other seasons. Nighttime mixing ratios were close to the LOD in summer and fall but were well above it in winters and springs of 2007-2009. Spring and winter 2010 at TF were exceptions with RGM mixing ratios mostly near the LOD.

Similar patterns and magnitude were observed for the spring- and summertime diurnal variation at AI. The most distinct difference in the diurnal variation between AI and $\mathrm{TF}$ was that more often than not nighttime mixing ratios at AI remained above the LOD, typically in the range of $0.2-$ 0.5 ppqv, except during fall 2009 which exhibited a higher range of $0.5-1.0$ ppqv. In general, RGM production in the marine boundary layer is considered to be facilitated by halogen radical chemistry which is driven by solar radiation. Non-zero RGM at night indicates possible nighttime production mechanisms (e.g., possibly involving degassing from aerosols and/or reactions involving $\mathrm{NO}_{3}$ ), despite rapid removal by dry and wet deposition, in the marine environment in summer and spring.

\subsection{3 $\mathrm{Hg}^{P}$}

Seasonal averaged diurnal cycles of $\mathrm{Hg}^{P}$ at TF and AI are illustrated in Fig. 10. Generally, $\mathrm{Hg}^{P}$ mixing ratios were higher in winter-spring and lower in summer-fall at TF compared to little variation at $\mathrm{AI}$ in all seasons except winter
2010. For both sites one distinctive feature is that compared to $\mathrm{RGM}, \mathrm{Hg}^{P}$ mixing ratios showed significantly smaller daily amplitudes and smaller seasonal variability at a specific time of the day. At TF the seasonal averaged daily amplitude was 0.4 and $0.2 \mathrm{ppqv}$ in winter and spring respectively, while it was negligible in summer and fall. It was $\sim 0.2 \mathrm{ppqv}$ at AI in spring, summer and fall. The 2010 wintertime diurnal cycle was uncharacteristically flat with mixing ratios remaining nearly constant at 0.1 ppqv.

The most prominent difference between the two sites lies in their diurnal patterns. At TF the daily maximum occurred at 17:00-20:00 UTC similar to RGM. However, at AI the pattern changed from season to season and from year to year, where the daily maximum occurred over 06:00-09:00 UTC in spring and summer 2009 compared to 17:00-20:00 UTC in fall 2009 and spring 2010. This large seasonal and yearto-year variability at $\mathrm{AI}$ indicates that the production and loss mechanisms controlling the ambient $\mathrm{Hg}^{P}$ level are more complex and probably multitudinous in the marine environment compared to coastal sites.

A closer examination revealed that RGM at AI was increased by 0.4 and 0.2 ppqv during the day in April and July, respectively, while $\mathrm{Hg}^{P}$ levels were quite constant throughout the day hovering around $0.1 \mathrm{ppqv}$ in April and $0.3 \mathrm{ppqv}$ in July. The RGM $+\mathrm{Hg}^{P}$ mixing ratios were less than $1 \mathrm{ppqv}$, which is $<1 / 10$ of the seasonal averaged daily loss of $\mathrm{Hg}^{0}$. This implies that the majority of the $\mathrm{RGM}+\mathrm{Hg}^{P}$ produced during the summer is quite possibly lost through wet and dry deposition, if we assume that: (1) the lost amount of $\mathrm{Hg}^{0}$ was transformed to $\mathrm{RGM}+\mathrm{Hg}^{P}$, (2) the loss of $\mathrm{Hg}^{0}$ during the day 

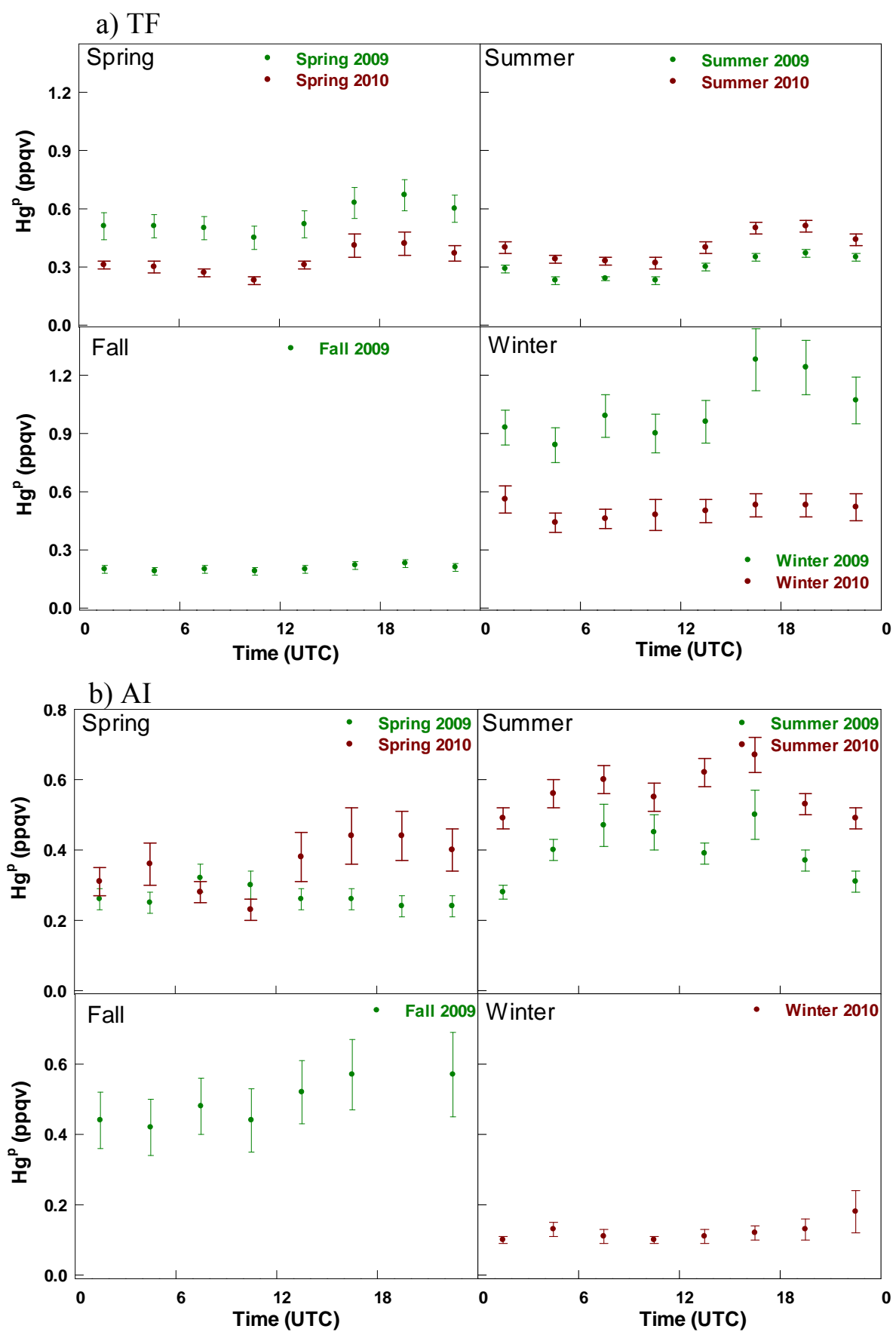

Fig. 10. Seasonally averaged diurnal cycles of $\mathrm{Hg}^{P}$ with standard deviation of means at TF (a) and AI (b).

was driven by oxidation while the total effect of deposition and oceanic emissions is similar in night- and daytime.

Lombard et al. (2011) calculated that the total wet deposition at TF in summer 2007 and 2008 were 3.02 and $6.37 \mu \mathrm{g} \mathrm{m}^{-2}$, which is approximately 338 and $750 \mathrm{ppqv}$ using an average PBL height of $1000 \mathrm{~m}$. In the same study they estimated a $2.31 \mathrm{~cm} \mathrm{~s}^{-1}$ dry deposition velocity of RGM in summer using an order-of-magnitude approach and three hourly mixing ratios of RGM and obtained a daily amount of dry deposition loss of RGM to be 92,46 , and 42 ppqv for summers 2007, 2008 and 2009. On a seasonal basis, the total loss of RGM from wet and dry deposition amounted to 430 and 796 ppqv in summers 2007 and 2008, which yields a daily average depositional loss of $\sim 5$ and $\sim 9$ ppqv, respectively. Assuming $\mathrm{Hg}^{P}$ levels and the dry deposition velocity of sea salt aerosols, on which most $\mathrm{Hg}^{P}$ resides (Feddersen et al., 
2012), are similar to those of RGM, it may not be far-fetched to hypothesize that the amount of $\mathrm{Hg}^{P}$ lost via dry deposition is comparable to that of RGM. Thus in summer a daily loss of RGM and $\mathrm{Hg}^{P}$ via wet and dry deposition may be close to 10-20 ppqv, which explains why the lowest ambient mixing ratios of $\mathrm{RGM}+\mathrm{Hg}^{P}$ occurred in summer.

\section{Summary}

In this study we present a comprehensive analysis of diurnal to interannual variability in $\mathrm{Hg}^{0}, \mathrm{RGM}$, and $\mathrm{Hg}^{P}$ at an inland rural elevated site, a coastal site, and a marine site. The common characteristics at the three sites were similar seasonal median mixing ratios of $\mathrm{Hg}^{0}$ and the reproducible annual cycle of $\mathrm{Hg}^{0}$ with maximum in winter-spring and minimum in fall, and the decline/increase in the warm/cool seasons. The coastal site TF differed from the other two sites with its exceptionally low levels (as low as $<50$ ppqv) in the nocturnal inversion layer in summer and early fall and peak levels frequently exceeding 250 ppqv leading to larger diurnal, seasonal, and annual variability. It was hypothesized that the low values were caused by loss via dissolution in dew water in the nocturnal inversion layer and subsequently, among other possibilities, the re-volatilization of $\mathrm{Hg}^{0}$ in the morning possibly comprised a significant fraction of the daytime peak level.

Decreasing trends in background $\mathrm{Hg}^{0}$ were identified in the 7.5- and 5.5-yr records at TF and PM with decline rates of $3.3 \mathrm{ppqv} \mathrm{yr}^{-1}$ and $6.3 \mathrm{ppqv} \mathrm{yr}^{-1}$, respectively. Year-to-year variability was observed in the warm season decline in $\mathrm{Hg}^{0}$ at TF varying from a minimum total seasonal loss of $43 \mathrm{ppqv}$ in 2009 to 92 ppqv in 2005, whereas variability remained small at $\mathrm{AI}$ and PM. Measurements of $\mathrm{Hg}^{0}$ at PM, the elevated rural site, exhibited the smallest diurnal to annual variability among the three environments, where peak levels rarely exceeded $250 \mathrm{ppqv}$ and the minimum was typically $100 \mathrm{ppqv}$. The results indicate that there were more complicated processes in the coastal and marine environments causing large temporal variability in $\mathrm{Hg}^{0}$.

It should be noted that summertime diurnal variation of $\mathrm{Hg}^{0}$ at $\mathrm{TF}$ and $\mathrm{AI}$ are opposite in phase indicating strong sink(s) for $\mathrm{Hg}^{0}$ during the day in the marine boundary layer, which is consistent with the hypothesis of $\mathrm{Hg}^{0}$ oxidation by halogen radicals there. Moreover, site differences suggest that at the elevated inland rural location (PM) interannual variability in ambient levels of $\mathrm{Hg}^{0}$ is driven largely by processes in summer, while in the coastal and marine environments (TF and AI) downwind of major source regions the net effect of all processes can vary greatly from year to year in all seasons but summer.

Mixing ratios of RGM at the coastal (TF) and marine sties (AI) reached the annual maximum in spring and minimum in fall, whereas at the rural elevated location (PM) they rarely went above the LOD except in spring. RGM levels at AI appeared to be larger than at TF and PM in most seasons indi- cating stronger source strength(s) in the marine environment, and nighttime levels at AI were often above the LOD. Diurnal variation of RGM was most pronounced with peaks during the day and minimums at night in spring and summer at $\mathrm{TF}$ and $\mathrm{AI}$ and at PM in spring only.

Mixing ratios of $\mathrm{Hg}^{P}$ at $\mathrm{AI}$ and $\mathrm{TF}$ were close in magnitude to RGM levels and were mostly below 1 ppqv. Observations at TF revealed that the annual maxima occurred in winter and the minima in fall, which is similar to the annual cycle of RGM. For $\mathrm{Hg}^{P}$ diurnal variation was barely discernible at TF and $\mathrm{AI}$ in spring and summer with higher levels during the day and levels that were smaller, but always above the LOD, at night in nearly all seasons.

Future work is warranted to understand mechanisms driving site differences and temporal variabilities of $\mathrm{Hg}^{0}$, RGM, and $\mathrm{Hg}^{P}$ in the three environments. In our Parts 2 (Mao et al., 2012) and 3 (Mao et al., 2012) we will investigate the relationships that $\mathrm{Hg}^{0}, \mathrm{RGM}$ and $\mathrm{Hg}^{P}$ may have with physical variables and other chemical compounds.

\section{Supplementary material related to this article is available online at: http://www.atmos-chem-phys.net/12/ 5099/2012/acp-12-5099-2012-supplement.pdf.}

Acknowledgements. Funding for this work is provided by the National Science Foundation under grant \# ATM1141713, the National Oceanic and Atmospheric Administration AIRMAP program under grant \#NA07OAR4600514, and the Environmental Protection Agency under contract \# EP09H000355. We thank Cheryl Parker and Kevan Carpenter for technical support. We thank J. Sigler for his work on initiating and maintaining RGM measurement at AIRMAP sites. We are also thankful to D. Kieber and the two anonymous reviewers' constructive comments.

Edited by: R. Cohen

\section{References}

Amos, H. M., Jacob, D. J., Holmes, C. D., Fisher, J. A., Wang, Q., Yantosca, R. M., Corbitt, E. S., Galarneau, E., Rutter, A. P., Gustin, M. S., Steffen, A., Schauer, J. J., Graydon, J. A., St. Louis, V. L., Talbot, R. W., Edgerton, E. S., Zhang, Y., and Sunderland, E. M.: Gas-particle partitioning of atmospheric $\mathrm{Hg}$ (II) and its effects on global mercury deposition, Atmos. Chem. Phys., 12, 591-603, doi:10.5194/acp-12-591-2012, 2012.

Berg, T., Kallenborn, R., Manø, S.: Temporal trends in atmospheric heavy metal and organochlorine concentrations at Zeppelin, Svalbard, Arct. Antarct. Alp. Res., 36, 283-290, 2004.

Cole, A. S., and Steffen, A.: Trends in long-term gaseous mercury observations in the Arctic and effects of temperature and other atmospheric conditions, Atmos. Chem. Phys., 10, 4661-4672, doi:10.5194/acp-10-4661-2010, 2010.

Ebinghaus, R., Kock, H. H., Coggins, A. M., Spain, T. G., Jennings, S. G., and Temme, C.: Long-term measurements of atmospheric 
mercury at Mace Head, Irish west coast, between 1995 and 2001, Atmos. Environ., 36, 5267-5276, 2002.

Ebinghaus, R., Jennings, S. G., Kock, H. H., Derwent, R. G., Manning, A. J., and Spain, T. G.: Decreasing trend in total gaseous mercury observations in baseline air at Mace Head, Ireland, from 1996 to 2009, Atmos. Environ., 45, 3475-3480, 2012.

Feddersen, D. M., Talbot, R., and Mao, H.: Size distribution of particulate mercury in marine and continental atmospheres, submitted to Atmos. Chem. Phys., 2012.

Fu, X., Feng, X., Zhu, W., Zheng, W., Wang, S., and Lu, J. Y.: Total particulate and reactive gaseous mercury in ambient air on the eastern slope of the Mt. Gongga, China, Appl. Geochem., 23, 408-418, 2008.

Kim, S. Y.: Continental outflow of polluted air from the U.S. to the North Atlantic and mercury cycling in various Atmospheric environments, $\mathrm{Ph}$. D. dissertation, 114 pp., University of New Hampshire, September 2010.

Lai, T.-L., Talbot, R., and Mao, H.: An investigation of two highest ozone episodes during the last decade in New England, Atmos., 3, 59-86, doi:10.3390/atmos3010059, 2012.

Landis, M. S., Stevens, R. K., Schaedlich, F., and Prestbo, E. M.: Development and characterization of an annular denuder methodology for the measurement of divalent inorganic reactive gaseous mercury in ambient air, Environ. Sci. Technol., 36, 3000-3009, 2002.

Laurier, F. and Mason, R.: Mercury concentration and speciation in the coastal and open ocean boundary layer, J. Geophys. Res., 112, D06302, doi:10.1029/2006JD007320, 2007.

Laurier, F. J. G., Mason, R. P., and Whalin, L.: Reactive gaseous mercury formation in the North Pacific Ocean's marine boundary layer: A potential role of halogen chemistry, J. Geophys. Res., 108, 4529, doi:10.1029/2003JD003625, 2003.

Lombard, M. A. S., Bryce, J., Mao, H., and Talbot, R.: Mercury wet deposition in southern New Hampshire, 2006-2009, Atmos. Chem. Phys., 11, 7657-7668, doi:10.5194/acp-11-76572011, 2011.

Lyman, S. N., Jaffe, D. A., and Gustin, M. S.: Release of mercury halides from $\mathrm{KCl}$ denuders in the presence of ozone, Atmos. Chem. Phys., 10, 8197-8204, doi:10.5194/acp-10-81972010, 2010.

Mason, R. P. and G.-R. Sheu: Role of the ocean in the global mercury cycle, Global Bio. Cycles, 16, 1093, doi:10.1029/2001GB001440, 2002.

Mason, R. P., Laurier, F. J. G., Whalin, L., and Sheu, G.-R.: The role of ocean-atmosphere exchange in the global mercury cycle, J. Phys. IV France, 107, 835-838, doi:10.1051/jp4:20030428, 2003.

Mao, H. and Talbot, R.: Role of meteorological processes in two New England ozone episodes during summer 2001, J. Geophys. Res., 109, D20305, doi:10.1029/2004JD004850, 2004a.

Mao, H. and Talbot, R.: $\mathrm{O}_{3}$ and $\mathrm{CO}$ in New England: Temporal variations and relationships, J. Geophys. Res., 109, D21304, doi:10.1029/2004JD004913, 2004b.

Mao, H., Talbot, R., Sigler, J. M., Sive, B. C., and Hegarty, J. D.: Seasonal and diurnal variation in $\mathrm{Hg}^{0}$ over New England, Atmos. Chem. Phys., 8, 1403-1421, doi:10.5194/acp-8-1403-2008, 2008.

Mao, H., Talbot, R., Hegarty, J., and Koermer, J.: Speciated mercury at marine, coastal, and inland sites in New England -Part 2: Re- lationships with atmospheric physical parameters, Atmos. Chem. Phys., 12, 4181-4206, doi:10.5194/acp-12-4181-2012, $2012 \mathrm{a}$.

Mao, H., Talbot, R., and Sive, B.: Long-term variation in speciated mercury at marine, coastal and inland sites in New England: Part 3. Relationships with Atmospheric Chemical Compounds, Atmos. Chem. Phys., in preparation, 2012 b.

Pirrone, N., Ferrara, R., Hedgecock, I. M., Kallos, G., G., Mamane, Y., Munthe, J., Pacyna, J. M., Pytharoulis, I., Sprovieri, F., Voudouri, A., and Wanberg, I: Dynamic processes of mercury over the Mediterranean region, Atmos. Environ., 37, S21-S39, 2003.

Rutter, A. P., Hanford, K. L., Zwers, J. T., Perillo-Nicholas, A. L., and Schauer, J. J.: Evaluation of an offline method for the analysis of atmospheric reactive gaseous mercury and particulate mercury, J. Air Waste Manage., 58, 377-383, doi:10.3155/10473289.58.3.377, 2008.

Schroeder, W. H. and Munthe, J.: Atmospheric mercury - an overview, Atmos. Environ., 5, 809-822, 1998.

Sheu, G.-R.: Speciation and distribution of atmospheric mercury: Significance of reactive gaseous mercury in the global mercury cycle, Ph.D. Thesis, University of Maryland, College Park, 170 pp., 2001.

Sigler, J. M. and Lee, X.: Gaseous mercury in background forest soil in the northeastern United States, J. Geophys. Res., 111, G02007, doi:10.1029/2005JG000106, 2006.

Sigler, J. M., Mao, H., and Talbot, R.: Gaseous elemental and reactive mercury in southern New Hampshire, Atmos. Chem. Phys., 9, 1929-942, doi:10.5194/acp-9-1929-2009, 2009.

Slemr, F., Brunke, E.-G., Ebinghaus, R., and Kuss, J.: Worldwide trend of atmospheric mercury since 1995, Atmos. Chem. Phys., 11, 4779-4787, doi:10.5194/acp-11-4779-2011, 2011.

Sprovieri, F., Pirrone, N., and Sommar, J.: Mercury speciation in the marine boundary layer along a $6000 \mathrm{~km}$ cruise path around the Mediterranean Sea, Atmos. Environ., 37, suppl. 1, S63-S71, 2003.

Sprovieri, F., Pirrone, N., Ebinghaus, R., Kock, H., and Dommergue, A.: A review of worldwide atmospheric mercury measurements, Atmos. Chem. Phys., 10, 8245-8265, doi:10.5194/acp10-8245-2010, 2010.

Steffen, A., Schroeder, W., Macdonald, R., Poissant, L., and Konoplev, A.: Mercury in the Arctic atmosphere: An analysis of eight years of measurements of GEM at Alert (Canada) and a comparison with observations at Amderma (Russia) and Kuujjuarapik (Canada), Sci. Total Environ., 342, 185-198, 2005.

Subir, M., Ariya, P. A., and Dastoor, A. P.: A review of uncertainties in atmospheric modeling of mercury chemistry I. Uncertainties in existing kinetic parameters - Fundamental limitations and the importance of heterogeneous chemistry, Atmos. Environ., 45, 5664-5676, 2011.

Subir, M., Ariya, P. A., and Dastoor, A. P.: A review of the sources of uncertainties in atmospheric mercury modeling II. Mercury surface and heterogeneous chemistry - A missing link, Atmos. Environ., 46, 1-10, 2012.

Talbot, R., Mao, H., Feddersen, D., Smith, M., Kim, S. Y., Sive, B., Haase, K., Ambrose, J., Zhou, Y., and Russo, R.: Comparison of particulate mercury measured with manual and automated methods, Atmosphere, 2, 1-20, doi:10.3390/atmos2010001, 2011.

Valente, R. J., Shea, C., Humes, K. L., and Tanner, R. L.: Atmospheric mercury in the Great Smoky Mountains compared to re- 
gional and global levels, Atmos. Environ., 41, 1861-1873, 2007.

Wilks, D. S.: Statistical Methods in the Atmospheric Sciences, Academic, San Diego, CA, USA, 467 pp., 1995.
Zhang, L., Wright, L. P., and Blanchard, P.: A review of current knowledge concerning dry deposition, of atmospheric mercury, Atmos. Environ., 43, 5853-5864, 2009. 